\title{
The resurgence of currency mismatches: Emerging market economies are not out of the woods yet?
}

\author{
Hari Venkatesh $^{1}$ (D) Gourishankar S. Hiremath ${ }^{1}$
}

Accepted: 29 April 2021 / Published online: 30 June 2021

(c) The Author(s), under exclusive licence to Springer-Verlag GmbH Germany, part of Springer Nature 2021

\begin{abstract}
The emerging market economies (EMEs) are experiencing significant financial distress due to the rapid accumulation of foreign currency-denominated debt in recent years. We develop the foreign exposure indicators such as original sin and currency mismatches using a novel data set. Our computations suggest that Latin American economies suffer from the original sin problem, followed by Central European countries. We find a higher degree of currency mismatches in Argentina, Chile, Colombia, Indonesia, Poland, Mexico, and Turkey. The resurgence of currency mismatches and the Covid-19 pandemic is a stress test for monetary policy frameworks. We find that country's size, inflation volatility, and exchange rate depreciation cause currency mismatches. We show that the currency mismatch and original sin problem are lower in countries following de-dollarization policies such as limiting debt exposure, effective monetary and fiscal policies, better institutional quality, and export openness. The EMEs need to adopt policies to control currency mismatches, which are consistent with their growth-oriented policies. We suggest the independence of monetary policy, the implementation of macroprudential policies, and the development of offshore bond markets in a local currency. These policies control currency mismatches without changing the growth orientation of the EMEs. South Africa, Hungary, and Asian economies hold lessons for EMEs in controlling currency mismatches.
\end{abstract}

\section{Highlights}

- Emerging market economies (EMEs) exposed to foreign currency risk and currency mismatches at an alarming level

- Latin America has greater original sin followed by central European economies

- Countries following de-dollarization policies lower the balance sheet vulnerabilities

- Forex reserves can safeguard EMEs from shocks emanating due to Covid-19 pandemic

- Independence of monetary policy, macroprudential policies, and development of offshore bond markets in a local currency control currency mismatches.

Hari Venkatesh

hari.venkatesh@iitkgp.ac.in

Extended author information available on the last page of the article 
Keywords Currency mismatches - Original sin hypothesis - Emerging market economies $\cdot$ Foreign currency debt $\cdot$ Financial vulnerability $\cdot$ Covid-19 pandemic

JEL Codes F30 $\cdot$ F31 $\cdot$ F34 $\cdot$ G01

\section{Introduction}

Since 2008, emerging market economies (EMEs) are experiencing significant financial distress and large output losses due to the large ebb and flow of foreign currencydenominated debt (FCD). The dollar debt issuance of EMEs has substantially grown to 134 percent from $\$ 1.57$ trillion in 2008 to $\$ 3.67$ trillion in 2018 (BIS 2019). ${ }^{1}$ Such growth has been owing to the low-cost source of capital but at the cost of currency risk. In addition, the share of FCD in GDP increased from 10.74 percent in 2007 Q4 to 16.5 percent in $2018 \mathrm{Q} 3$, indicating an alarming sign of external sector vulnerability in EMEs (Fig. 1). The high level of FCD possibly leads to a currency mismatch problem, which, in turn, increases the likelihood of financial crises. On this count, it is clear that the Covid-19 and consequent lockdown of economies can lead to destabilizing effects on EMEs. Therefore, there is a need to measure foreign currency exposure to assess recent external vulnerability and financial distress. In this context, we evaluate the external vulnerabilities in EMEs by developing a method to measure exposure. We also investigate the factor responsible for such exposures.

The EMEs raise the capital from international markets in foreign currency as they find it difficult to borrow in their own currency. This inability to borrow in own currency is termed as 'original sin' (Eichengreen et al. 2005a, b). The original sin results in a 'currency mismatch' in the assets and liabilities of the country. Currency mismatch is defined as the mismatch between currency composition of liabilities and assets where the assets are denominated in domestic currency but liabilities in foreign currency (Goldstein and Turner 2004). We measure the original sin and currency mismatches in EMEs to examine the extent of external vulnerability. Nevertheless, the foreign currency borrowings boost the production and output in EMEs (Hiremath 2016). Therefore, while the currency mismatches suggest vulnerability, the debt cannot be completely averted as leverage is essential for the economic growth.

The EMEs are posed with significant challenges, such as a slowdown in growth rate, higher sensitivity to the exchange rate risk, and capital volatility. The exchange rate pass-through is higher in EMEs than in advanced economies, and therefore the fallout of currency mismatch will be devastating in the former than the latter (BIS 2019). Thus, the growing FCD and original sin can hurt the balance sheet of EMEs in the event of exchange rate depreciation. The local currency bond spread sharply rises in the event of exchange rate depreciation and capital outflows due to Covid-19 (Hofmann et al. 2020).

On the other hand, foreign currency risk can be hedged by earning forex reserves through exports (Goldstein and Turner 2004). For instance, Chinese Taipei and

\footnotetext{
${ }^{1}$ The debt of EMEs is primarily denominated in the US dollar ( $\$ 3.67$ trillion), Euro ( $\$ 792$ billion), and Japanese yen ( $\$ 72$ billion).
} 


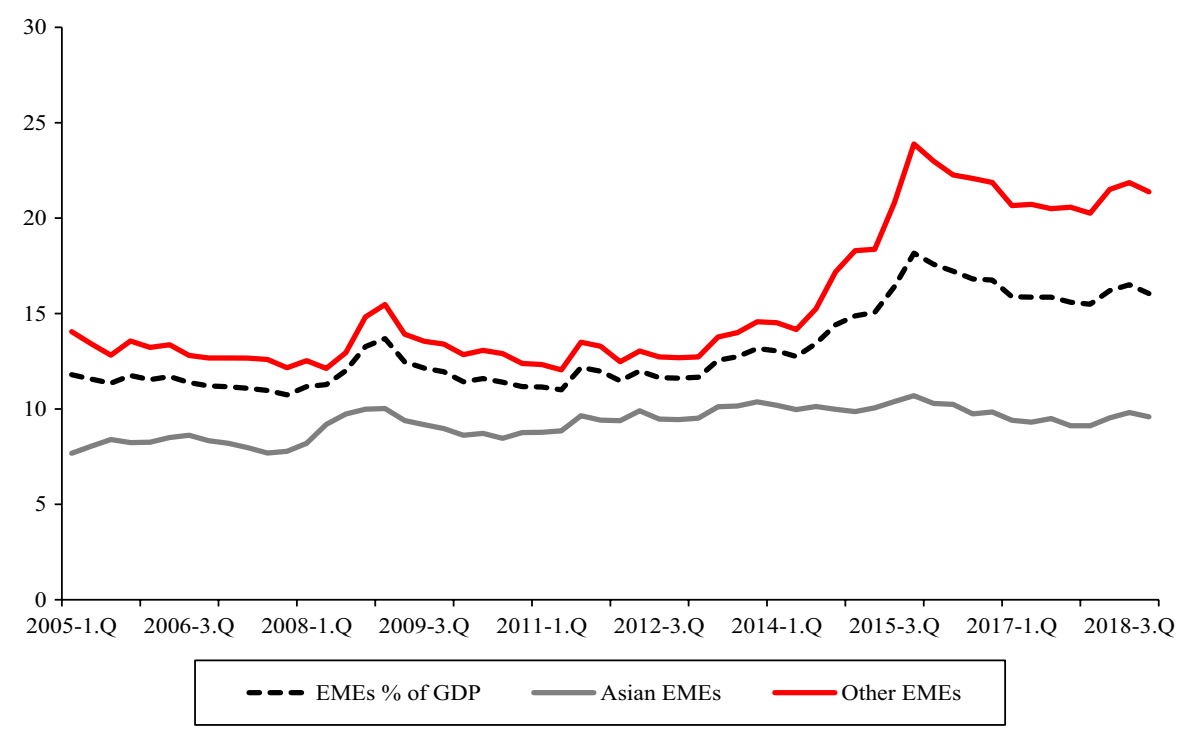

Fig. 1 Foreign currency-denominated debt (FCD \% of GDP). Source: Prepared from the data collected from the Bank of International Settlements (BIS)

China sustained larger FCD levels as they accumulated a considerable amount of foreign currency assets ( $215 \%$ and $166 \%$ of exports, respectively). Therefore, measuring both assets and liabilities in foreign currency reveals the severity of currency mismatch problems in aggregate balance sheets. Further, computation of currency mismatches at the aggregate level can help policymakers to make the right decisions apposite to external risk.

Less is known about the recent developments in foreign currency exposure of EMEs, especially that of the corporate sector. Studies such as Goldstein and Turner (2004), Eichengreen et al. (2007), and Chui et al. (2018) document that EMEs lengthened their foreign currency exposure. The FCD and currency mismatches have been associated with a higher incidence of financial crises in the past. Still, little attention is paid to the topic of currency mismatches in the recent past despite staggering growth in such mismatches. Eichengreen et al. (2005a, b, 2007), Goldstein and Turner (2004), Park (2011), and Chui et al. (2018) emphasize the need for a comprehensive method of measuring currency mismatches in EMEs. To the best of our knowledge, no study probes recent developments in currency mismatches and implications of such trends. Hence, this paper fills these gaps in the literature by analyzing the current evolution in foreign currency exposure and currency mismatches in EMEs.

We contribute to the literature on foreign currency exposure and external vulnerabilities by analyzing the evolution of FCD, currency mismatches, and policy implications. To do so, we put together and analyze the variety of data sets on foreign currency exposure. First, we examine the issuance of international debt securities encompassing the currency composition of external debt. We compute the original sin index for the EMEs using granular data on global debt securities. Second, we complement the 
information on original sin values with country-level data on the share of foreign currency debt in total debt outstanding. Third, we also use the balance sheet information to calculate the net asset position in foreign currency and examine currency mismatches. Using these indices, we take a fresh look at the role of original sin and foreign currency debt in influencing currency mismatches. One of the main contributions of this paper is to show the resurgence of currency mismatches in EMEs since the post-global financial crisis (GFC). Finally, we examine the factors responsible for the currency mismatches and original sin and offer policy inputs to manage external vulnerability.

The computation of currency mismatches reveals a higher degree of currency mismatches in Argentina, Chile, Colombia, Indonesia, Poland, Mexico, and Turkey, indicating the likelihood of financial crises. We show that the currency mismatch problem is lower in countries that follow de-dollarization policies such as limiting debt exposure, effective monetary and fiscal policies, better institutional quality, and export openness. The findings suggest the crucial role of foreign currency assets, macroprudential policies, and domestic bond markets in limiting currency mismatches and enhancing the resilience of the financial system in the event of a crisis.

The rest of the paper is organized as follows. The conceptual framework and analytical issues of currency mismatches are discussed in Section 2. In Section 3, we present the recent trends in currency mismatches and important insights into policy conflicts. We discuss the factors responsible for currency mismatches and original sin in Section 4 . The last section concludes the paper with policy implications.

\section{Conceptual framework}

\subsection{Original sin hypothesis}

In their theory of original sin, Eichengreen et al. (2005a) define sin as "the inability of a country to borrow abroad in its own currency." The original sin occurs when the economies exhibit a lack of monetary creditability, low credit ratings, and volatile capital flows and output. Overall, the incompleteness in financial markets is the cause of original sin. Many of the EMEs are unable to borrow for long-term maturity from the domestic markets. Such inability can be termed as the domestic original sin. Eichengreen et al. (2005a) construct three indices of original $\sin (O S I N)$ :

$$
\text { OSIN1 }=1-\frac{\text { Securities issued by country } i \text { in currency } i}{\text { Securities issued by country } i}
$$

when the county issues all the securities in domestic (foreign) currency, OSIN1 is zero (one). However, OSIN1 does not include hedging instruments. Hence, the OSIN2 index includes hedging instruments such as swaps. Finally, the OSIN3 is a comprehensive measure that encompasses OSIN2 and long-term debt indexed to prices and imposes lower bounds:

$$
\text { OSIN3 }=\max \left(1-\frac{\text { Securities in currency } i}{\text { Securities issued by country } i}, 0\right)
$$


The original sin index ranges between zero and one. The value closer to one implies an extreme level of original sin position, whereas the lower value suggests a secure position. Nevertheless, Goldstein and Turner (2004) criticize the original sin indices as a measure of currency mismatches on several grounds. First, original sin indicators consider the liability side of the balance sheet effect. In the real-world, both assets and liabilities are used to hedge foreign exchange positions. Second, the original sin framework ignores the essential inputs such as the differences in export openness, the size of the foreign assets, and reserve holdings to assess currency risks. Third, original sin indicators exclude foreign currency assets and receipts over time. Finally, the original sin index does not consider international bonds and bank loans. In order to overcome these limitations, we measure currency mismatches.

\subsection{Currency mismatches}

In seminal work, Goldstein and Turner (2004) define the currency mismatches as "how the change in the exchange rate will affect the present discounted value of the future income and expenditure flows." Currency mismatches refer to the mismatches between assets and liabilities of a country, sector, or firm, in which the liabilities are denominated in foreign currency and assets or revenue in domestic currency. In the event of exchange rate depreciation, the value of liabilities increases, thereby aggravating the currency mismatch problem further. As a result, currency mismatches lead to financial instability in EMEs. Moreover, the exchange rate changes affect the financial position through stock and flow channels. The sensitivity of the balance sheet to changes in the exchange rate is called a 'stock aspect of currency mismatches.' On the other hand, the sensitivity of income statements to changes in the exchange rate is known as the 'flow aspect of currency mismatches.'

\subsection{The measurement of currency mismatches}

The literature discusses various methods to measure currency mismatches. The earliest measure of currency mismatches in the literature is the original sin hypothesis. Later, Goldstein and Turner (2004) construct an aggregate effective currency mismatch $(A E C M)$ index to overcome the drawbacks of original sin indicators. They consider external vulnerability indicators at the aggregate level using the residence principle and include both sides of the balance sheet items. The AECM is calculated as follows:

$$
\begin{array}{ll}
A E C M_{i, t}=\frac{N F C A_{i, t}}{M_{i, t}} \times F C T D_{i, t} & \text { if } N F C A_{i, t}>0 \\
A E C M_{i, t}=\frac{N F C A_{i, t}}{X_{i, t}} \times F C T D_{i, t} & \text { if } N F C A_{i, t}<0
\end{array}
$$


where $N F C A$ is the net foreign currency assets. ${ }^{2} M$ and $X$ are the country's imports and exports of goods and services, respectively; FCTD represents the foreign currency share of the total debt. ${ }^{3} A E C M>0$ indicates the net asset position in a country's foreign currency, whereas the $A E C M<0$ suggests the net liability position. When foreign currency liabilities are equal to assets of the country $i$ and year $t$, $A E C M=O$ (no currency mismatch). The exchange rate depreciation causes a negative balance sheet as well as competitiveness effect when there is a net liability position. On the other hand, the net asset position can have a positive balance sheet and competitiveness effect.

The AECM method, although a sophisticated measure, has some limitations. First, the external vulnerabilities ideally need to be based on currency denomination rather than residence principle since each country's financial relations are associated with the rest of the world (Levy-Yeyati 2006; Eichengreen et al. 2007; Tobal 2013). Second, the AECM underestimates the balance sheet problem in the case of net asset position in foreign currency. Third, Lane and Shambaugh (2010) argue that AECM neglects the components of capital flows such as foreign direct investment (FDI) and portfolio investment (FPI). ${ }^{4}$ Hence, this method does not capture the full currency composition of an international balance sheet.

Further, the trade-weighted exchange rate indices are insufficient to understand the financial impact of currency mismatches. Therefore, Lane and Shambaugh (2010) consider the dual role of the exchange rate and its variation in international currency exposure. ${ }^{5}$ Moreover, AECM covers the internal foreign currency exposure, i.e., one resident to another resident's bank and bond financing in foreign currency. This index does not include offshore finance vehicles.

Unlike Goldstein and Turner's (2004) measure of currency mismatch. Kuruc et al. (2016) and Chui et al. (2018) develop a new method to overcome the limitations of ACEM. This method combines two distinct components of currency mismatches:

$$
\begin{gathered}
M R_{i, t}=\frac{F C T D_{i, t}}{X G D P_{i, t}} \\
A E C M_{i, t}=M R_{i, t} \times\left(\frac{N F C A_{i, t}}{G D P_{i, t}}\right)
\end{gathered}
$$

\footnotetext{
${ }^{2}$ NFCA $>0$ implies net asset position in foreign currency, and net liability position in foreign currency represents NFCA $<0$ that leads to currency mismatches. The NFCA consists of "net foreign assets of monetary authorities and deposits of money banks, and foreign currency assets of non-banks held with BIS reporting banks minus foreign currency liabilities of non-banks to BIS reporting banks international debt securities outstanding".

${ }^{3}$ The FCTD is comprised of "liabilities of non-banks and non-banks to BIS reporting, domestic credit to the private sector, international and domestic debt securities outstanding".

${ }^{4}$ The equity-related instruments like FDI and FPI are excluded in AECM as they may not have the characteristics of FCD and FCA.

${ }^{5}$ Lane and Shambaugh's (2010) innovative contribution is to construct the financial weight of exposure for relevant currency and each country.
} 
Table 1 List of selected EMEs

\begin{tabular}{llll}
\hline Asia & Central Europe & Latin America & Other EMEs \\
\hline China & Czech Republic & Argentina & Russia \\
Chinese Taipei & Hungary & Brazil & Israel \\
India & Poland & Chile & Turkey \\
Indonesia & & Colombia & South Africa \\
Malaysia & & Mexico & \\
Philippines & & Peru & \\
South Korea & & Venezuela & \\
Thailand & & & \\
\hline
\end{tabular}

where $M R_{i, t}$ is the mismatch ratio; $F C T D_{i, t}$, and $X G D P_{i, t}$ denote foreign currency share of total debt and the ratio of exports of goods and services to GDP of country $i$ and year $t$. The $F C T D_{i, t}$ is a much broader component than external debt denominated in foreign currency. The $N F C A_{i, t}$ stands for the net foreign currency asset position. ${ }^{6}$ Kamil (2012) and Montoro and Rojas-Suarez (2012) use the proxies such as a ratio of dollar debt to the sum of exports and dollar assets; and the ratio of foreign currency debt to total debt as a percentage of exports in GDP. However, these currency mismatch ratios do not capture the foreign currency exposure in its entirety.

In a nutshell, the extant literature treats currency mismatch with financial risk indicators like original sin and ratio of broad money to reserves. Moreover, the measurement of currency mismatches is challenging due to the lack of data and a comprehensive method to capture foreign currency exposure. The AECM method is based on the residency principle and covers internal foreign currency exposure. Kuruc et al. (2016) and Chui et al. (2018) extends the AECM methodology. This improved method is not yet empirically tested. Therefore, we analyze the foreign currency exposure and currency mismatches by employing these methods. Besides, we probe the factors responsible for aggregate currency mismatches.

\section{The empirical analysis}

\subsection{Data}

We employ a novel method suggested by Kuruc et al. (2016) and Chui et al. (2018) to measure the currency mismatches. Our sample includes 22 EMEs for the period 2008-2018. The sample comprises seven Latin American economies, three Central European countries, eight Asian economies, and four other EMEs (Table 1). The Bank for International Settlements (BIS) publishes statistics on cross-border

\footnotetext{
${ }^{6}$ NFCA computed as "the sum of (i) the net foreign assets of the central banks and other depository corporations plus (ii) non-bank foreign currency cross-border assets with BIS reporting banks minus (iii) non-bank foreign currency cross-border liabilities (excluding debt securities) to BIS reporting banks, minus (iv), non-bank international debt securities outstanding in foreign currency".
} 
Table 2 Original sin by country groupings (average)

\begin{tabular}{lll}
\hline Region & $2008-12$ & $2013-18$ \\
\hline Latin America & 0.85 & 0.90 \\
Central Europe & 0.63 & 0.84 \\
Asia & 0.73 & 0.72 \\
Other EMEs & 0.57 & 0.66 \\
\hline
\end{tabular}

Source: Authors' own calculations based on BIS data

This table shows the average original sin index values computed for 20 EMEs during 2008-2018. The original sin index value ranges between zero and one. The value closer to one indicates severe original sin problem implying a higher currency risk

banking flows and debt securities of few countries. Therefore, our sample is confined to 22 EMEs. The analysis of foreign currency exposure and currency mismatches assumes importance as many EMEs are under financial stress. The COVID19 pandemic is threatening the financial stability of these economies. Moreover, currency depreciation of EMEs against the US dollar increases external debt and rollover crisis. The present study covers the recent period, which helps policymakers devise a policy framework to deal with financial stress and the crisis.

\subsection{Measure of original $\sin (\mathrm{OSIN})$}

We compute the original sin index (Eq. 2) using a dataset on international debt securities and loans, but the index does not include cross-border bank loans. Original sin is primarily due to incompleteness in financial markets, credit ratings, and volatile capital flows. The exchange rate depreciation against the dollar tends to increase the value of the original sin and make it harder to repay the debt denominated in foreign currency. The average OSIN index indicates higher levels of original sin in the Latin American economies than that of other regions. The value of the sin increased from 0.85 to 0.90 between 2008-2012 and 2013-2018 (Table 2). Except for Asia, the average original sin rose in all the regions due to financial stress during 2008-2018. The taper tantrum crisis, China's slowdown, trade wars, and lira/peso crisis were responsible for such stress of assets. Therefore, we can observe a clear difference in OSIN values between 2008-2012 and 2013-2018.

Further, the average original sin value at the country level presented in Fig. 2 shows a greater extent of original sin in Argentina, Chile, and Venezuela (OSIN value is close to one). Such a level of sin implies a high degree of foreign currency risk. Similarly, Hungary, Chinese Taipei, Malaysia, the Philippines, and Israel suffer from the original sin problem. Although the Czech Republic had no original sin risk during 2008-2009, the level of sin increased to 0.73 during later years. This rise in the Czech Republic's vulnerability resulted from an increase in Euro-denominated debt to 22.2 percent of total GDP in 2018 (IIF 2019). Overall, the problem of original sin increased in all EMEs after the taper tantrum crisis during the year 2013.

In the Asiatic region, China and India have a lower value of original sin compared to other EMEs. India reduced the OSIN from 0.98 to 0.54 between 2008 
(a) Latin America

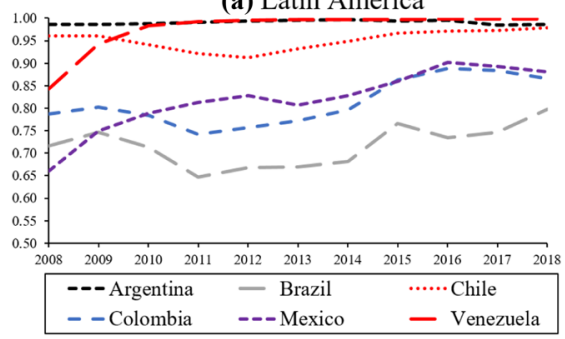

(c) Asian Economies

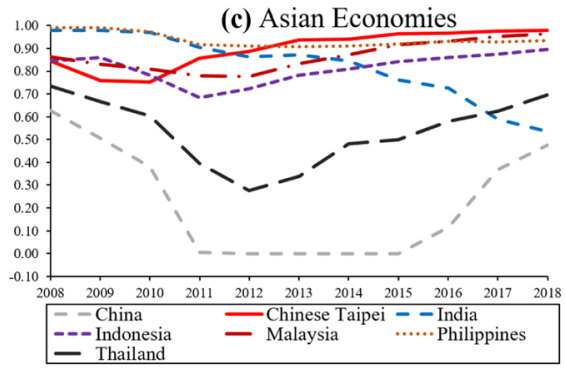

(b) Central Europe

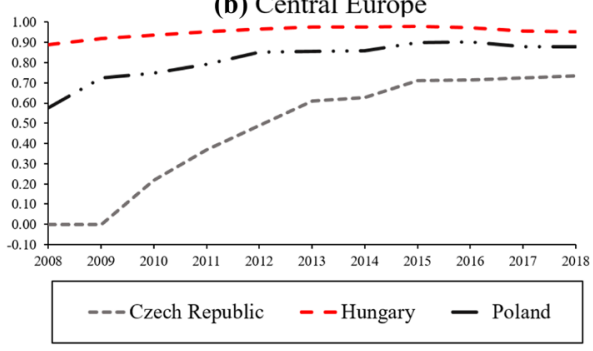

(d) Other EMEs

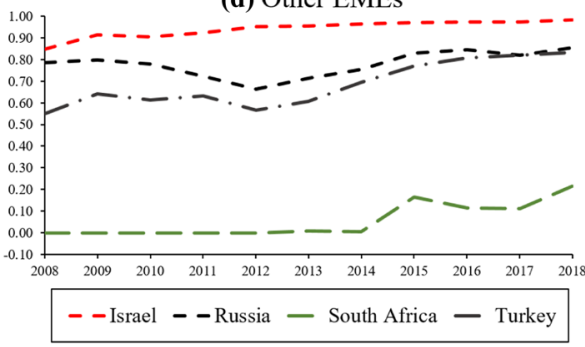

Fig. 2 Original sin by country wise. Notes: The original sin index values are based on the sample of 20 EMEs for the period 2008 to 2018. The details of countries are also provided in Table 1 . The original sin index value ranges between zero and one. The index value closer to one indicates a severe original sin problem. Such sin implies a higher currency risk. Source: Authors' own calculations based on the Bank for International Settlements (BIS) database on international debt securities. The annual average is computed from the quarterly data

and 2018 (Fig. 2). The issuance of rupee-denominated bonds - masala bonds in the international market is one of the policy measures that reduced the debt. The OSIN in China was reduced to zero, but it rose to 0.47 after 2015, leading to the saucer-shape curve. China started the renminbi-denominated bond market, popularly known as dim sum bonds. These bond issuances substantially increased after 2010 and reached their highest level in 2014. In 2015 and later periods, the dim sum bond issuances dropped drastically due to currency devaluation, financial instability, and trade tensions (Kohli et al. 2017).

Interestingly, South Africa has the lowest $O S I N$ values among all sample countries, and the country cautiously dealt with the foreign currency risk by issuing debt in rand-denominated bonds. South Africa borrowed only 5.5 percent of gross government debt in foreign currency. The sophisticated financial markets attracted foreign investors to local bond markets, which led to 37 percent of investment in government bonds. These markets acted as a bulwark for South Africa. When the rand depreciates against the dollar, the government need not pay foreign debtors.

Moreover, South Africa has managed the sovereign debt levels effectively than its counterparts. The country met the financial needs sustainably, using deep and liquid financial markets. With these favorable conditions, a country can easily follow the floating exchange rate regime that increases export competitiveness during the depreciation period. 

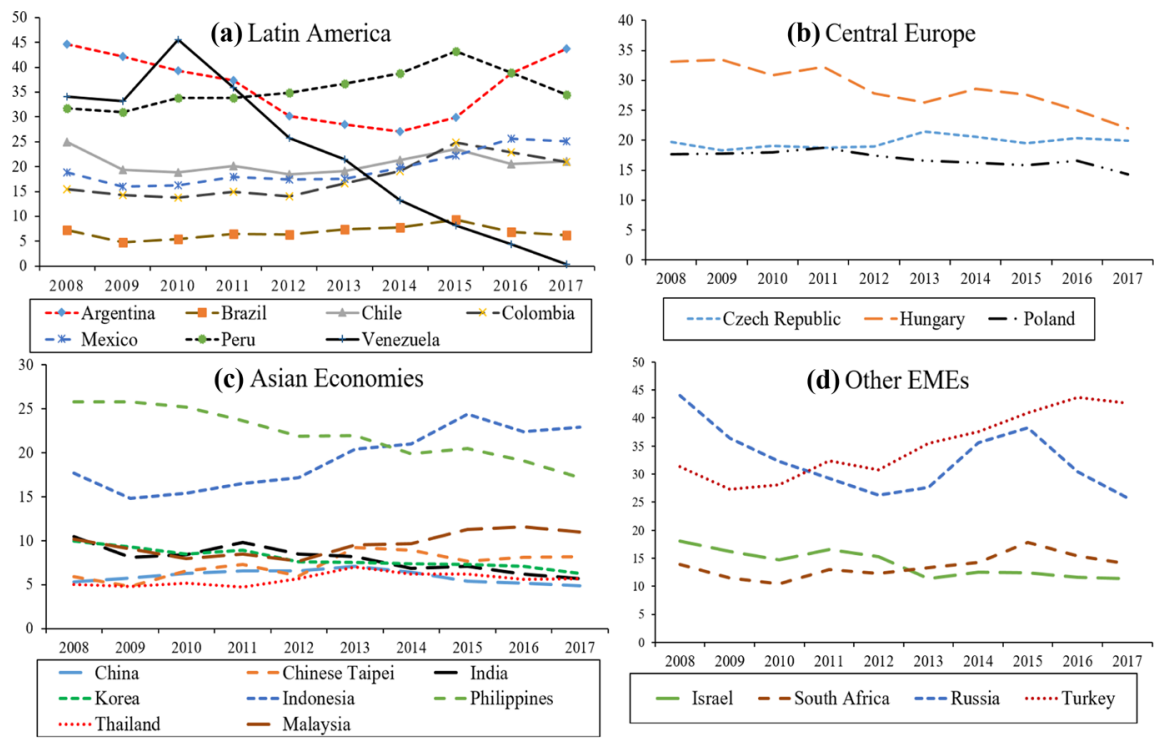

Fig. 3 Foreign currency shares of total debt outstanding (FCTD). Data Sources: Bank for International Settlements (BIS) locational banking statistics and debt securities statistics; International Monetary Fund (IMF)

\subsection{Foreign currency share in total debt outstanding (FCTD)}

FCTD is a comprehensive measure that includes the country's total liability denominated in foreign currency. Moreover, this indicator is broader than external debt denominated in foreign currency. We compute the first indicator of currency mismatch - FCTD by assuming the denomination of domestic bonds and bank loans exclusively in local currency. We observe that the value of FCTD is lower than the international debt securities and cross-border bank loans in EMEs (Fig. 3). The FCTD increased after the GFCs and peaked in 2015. The FCTD is higher in the Latin American region: Argentina, Mexico, and Colombia raised FCTD to 43.7, 25.1, and 20.5 percent in 2017, respectively. On the other hand, Central Europe has moderately reduced FCTD between 2008 and 2017.

Similarly, the share of foreign currency in total debt in Asian economies such as China, Chinese Taipei, India, Malaysia, Russia, South Korea, and Thailand is lower than that of their peers. For example, India and Russia slashed their share of foreign currency debt from 10.5 to 5.7 percent and 31 to 12.4 percent, respectively. Further, Venezuela had successfully reduced FCTD to 0.3 percent in 2017 from the highest 45.5 percent in 2010.

Among the Latin American countries, Brazil has the lowest share of foreign currency in its total debt and remained flat over the period (7.2 and 6.2 percent in 2008 and 2017). To reduce the FCD, Brazil has started to issue real denominated bonds in the domestic market. Brazil has issued $\$ 7.08$ billion worth of local currency bonds 


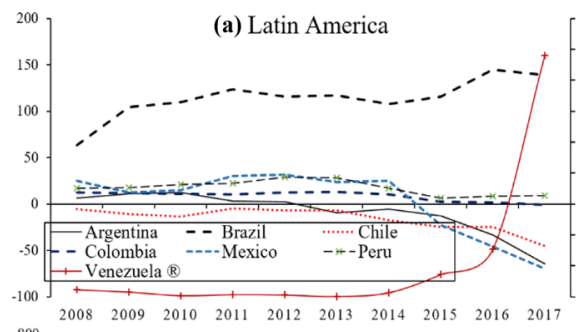

(b) Central Europe
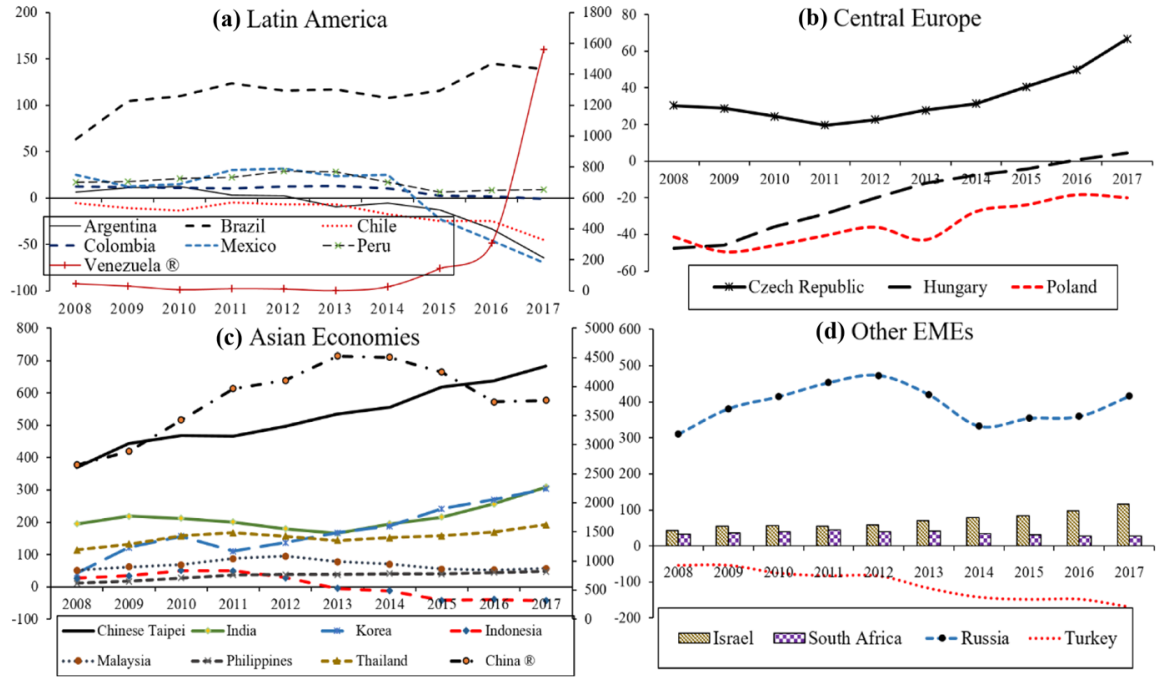

(d) Other EMEs

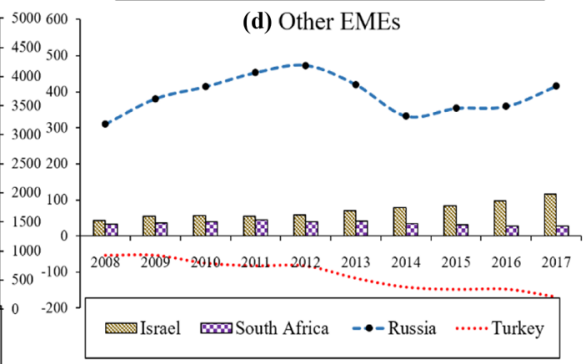

Fig. 4 Net foreign currency asset position. Data Sources: Bank for International Settlements (BIS) locational banking statistics and debt securities statistics; International Monetary Fund (IMF). Note: The figure presents the net foreign currency asset position (NFCA) in billion US \$. China's foreign currency assets are measured on the right side

in the offshore market with a similar maturity period as the US dollar-denominated bonds (Kohli et al. 2017). Further, Brazil has a well-developed domestic capital market than other Latin American countries. Therefore, Brazil's success in lowering FCD can be a lesson for other EMEs to lessen its foreign currency risk.

The experience in the past shows that FCD tends to increase before financial crises. The FCD rose significantly in Argentina, Indonesia, and Turkey in recent years. This staggering rise suggests greater exposure to external vulnerability and an increase in the likelihood of financial crises. Further, the rapid accumulation of FCD in EMEs increases financial stress and threatens financial stability with stable economic conditions in the US. The stable policy framework in the US further narrows the intervention of central banks and fiscal authorities of EMEs in their debt markets.

\subsection{Net foreign currency assets position (NFCA)}

We present the NFCA position, the second component of currency mismatch, in Fig. 4. The NFCA explains how a large volume of currency mismatches poses a problem and how a country sustains even if it has high FCD and original sin. An economy with a high net foreign liability (asset) position faces the adverse (positive) balance sheet effect in case of exchange rate depreciation.

We observe the net liability position in aggregate balance sheets of Argentina, Chile, Colombia, Indonesia, Hungary, Mexico, Poland, and Turkey over the past decade (Fig. 4). Brazil, Czech Republic, China, Chinese Taipei, India, Israel, Philippines, South Korea, Russia, Thailand, and Venezuela registered the growth in 
the NFCA position, which can be attributed to higher foreign exchange earnings. The rise in "cross-border bank deposits of non-banks with BIS reporting banks" is another significant reason for the NFCA position in EMEs (Chui et al. 2016). Nevertheless, the positive NFCA turned into negative and increased the foreign currency liability position in Argentina, Mexico, and Indonesia. The increased share of foreign currency debt in total debt explains such a shift (Fig. 3).

Hungary is the only country to succeed in transforming the net liability position to the net asset position. Hungary reduced the liabilities position by $\$ 47.6$ billion as well as raised the foreign currency assets worth $\$ 4.4$ billion (current account surplus). Hungary is successfully pursuing an export-led growth strategy. On the other hand, many EMEs reached the highest negative value of NFCA in 2017, such as Turkey (\$168.9 billion), Mexico ( $\$ 69.9$ billion), Argentina ( $\$ 64.6$ billion), Chile ( $\$ 45.3$ billion), Indonesia ( $\$ 43.3$ billion), Poland ( $\$ 20.1$ billion) and Colombia ( $\$ 11.1$ billion). In Argentina and Turkey, the new lira and peso crises furthered the negative position in foreign currency.

\subsection{Aggregate effective currency mismatches (AECM)}

$A E C M$ is the combination of two indicators - FCTD and NFCA normalized with either exports or imports. Suppose the economy has a net liability position in foreign currency $(\mathrm{NFCA}<0)$ or FCA $<$ FCL. In such a case, we use the exports as the denominator in the $A E C M$ (Eq. 6); otherwise, we utilize imports. A negative value of $A E C M$ suggests the net liability position in foreign currency. In the event of exchange rate deprecation, the net liability position leads to a negative balance sheet (net worth falls) and a positive competitiveness effect (imports falls and exports rise). On the other hand, the net asset position in foreign currency generates a positive impact on the balance sheet and competitiveness.

The trend shows that currency mismatches increased from 2010 and remain high in EMEs due to the steep fall in foreign currency assets (Fig. 5). Moreover, the unstable monetary policy and dollarization of debt are responsible for such mismatches. The magnitude of the currency mismatch problem becomes severe in the case of the negative value of AECM. On this count, Argentina, Chile, Colombia, Indonesia, Mexico, Poland, and Turkey suffered from high currency mismatches. Mexico has larger export earnings in excess of dollar debt. Nevertheless, the country registered larger currency mismatches during 2013-2017 due to the higher level of original sin (0.86) (Fig. 2).

On the other hand, China, the Czech Republic, and Israel achieved a favorable position in foreign currency because of a stronger position in foreign currency assets of the official sector (Chui et al. 2016). These economies held substantial levels of forex reserves and reduced the sovereign debt in foreign currency. For example, China succeeded in limiting currency mismatches by issuing the dim sum bonds (denominated in a local currency, yuan). Hungary also lowered the magnitude of currency mismatches in its balance sheet by cutting down the external debt from 54.6 to 13.3 percent of GDP between 2010 and 2017. This improvement is due to the strategic refinancing of sovereign debt in the local currency forint. 

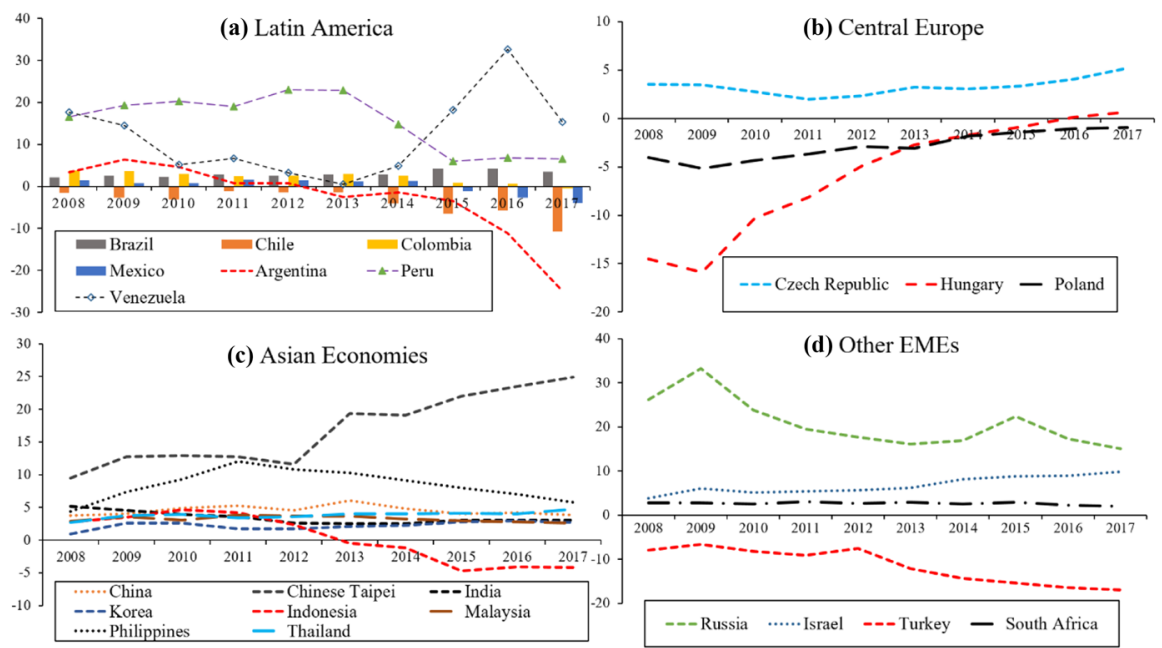

Fig. 5 The aggregate effective currency mismatches (AECM). Data Source: Authors' calculations based on data from the Bank for International Settlements (BIS), International Monetary Fund (IMF), and World Bank. Note: Y-axis measures AECM (\%). The negative values show that EMEs have high-level currency mismatches

Currency mismatches tend to increase preceding the financial crises (exacerbate the currency, debt, and banking crisis) as happened in the Tequila crisis (1994) and the Asian financial crisis (1997). Hence, the mismatches often are indicators of an impending crisis. In a similar vein, our findings suggest an association between the recent currency crisis in Argentina and Turkey and the greater currency mismatches in their balance sheets. This evidence is consistent with the argument that currency mismatches increase the likelihood of financial crises (see Goldstein and Turner 2004; Eichengreen et al. 2007; Gagnon 2014; Chui et al. 2018). Moreover, the rapid accumulation of private sector debt in EMEs causes a financial shock in the balance sheets. Recently, the steep rise of non-financial corporate debt from 60.4 to 104.3 percent of GDP from 2008 to 2018 indicates an alarming sign of financial sector vulnerability in these economies. On the other hand, the debt remains stable ( 92.4 to 91.7 percent of GDP) in advanced economies during the same period (Fig. 6).

The recent literature suggests that EMEs have avoided the original sin and currency mismatch problem by borrowings in their own currency from the international market (Du and Schreger 2016; Arslanalp and Tsuda 2014). Nevertheless, our measures show that the value of the original sin and currency mismatch problem accelerated after the GFC. For instance, Indonesia is suffering from a currency mismatch problem since 2013 and facing an external vulnerability risk similar to uncertainty during the Asian crisis. Venezuela holds a high amount of sovereign external debt, which rose to $\$ 156$ billion in 2018. We reject the finding of Kuruc et al. (2016) that aggregate currency 


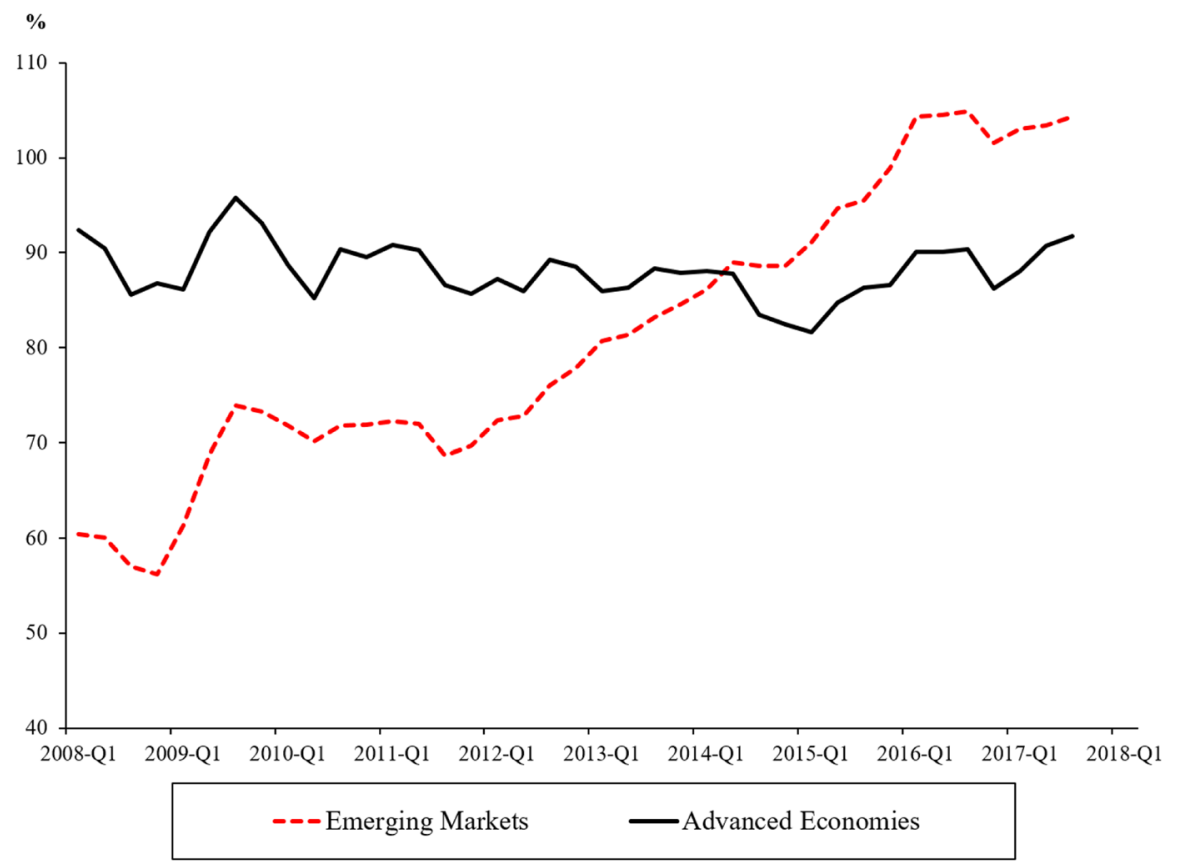

Fig. 6 Total credit to the non-financial corporations. Data Source: Consolidated banking statistics, Bank for International Settlements (BIS). Note: The figure presents the total credit to the non-financial corporations as a percentage of GDP (Y-axis) for emerging markets and advanced economies (X-axis)

mismatches can no longer be the problem. Our evidence is not the only novel but also significant from the policy point of view.

In light of preceding evidences and discussion, the understanding of causes of original sin and currency mismatches is indispensable. Such an analysis gives insights into working of currency mismatch and possible solutions to deal with it. In a globalizing world, the foreign currency borrowings are important for the firms and government for various reasons. A complete aversion to such borrowing affects the economic growth. Therefore, our analysis of factors help to find the solutions without affecting the growth.

\section{The causes of currency mismatches and original sin}

In this section, we investigate the causes of currency mismatches and original sin. The extant literature identifies factors such as ineffective monetary and fiscal policies, volatile exchange rates, and poor quality institutions as root causes of currency mismatches (Goldstein and Turner 2004; Baek 2013). In the same vein, Eichengreen et al. (2005a, b, 2007) investigate the causes of original sin. Based on the prior theoretical and empirical framework, we specify our panel regression model as follows:

$$
Y_{i, t}=\alpha_{i}+\beta_{1} \operatorname{Size}_{i, t}+\beta_{2} I V_{i, t}+\beta_{3} E V_{i, t}+\beta_{4} E X_{i, t}+\beta_{5} I Q_{i, t}+\beta_{6} M I_{i, t}+\beta_{7} M P_{i, t}+\beta_{8} E D_{i, t}+\varepsilon_{i, t}
$$




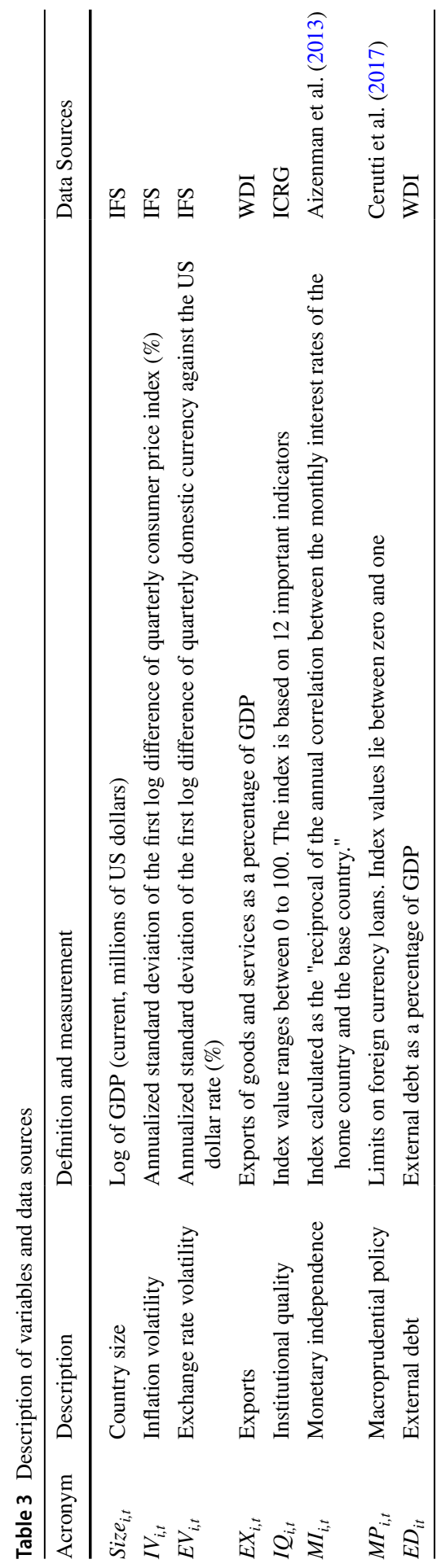


Table 4 Fixed-effect regression: causes of currency mismatches

\begin{tabular}{|c|c|c|c|c|c|c|}
\hline \multirow[b]{2}{*}{ Variables } & \multicolumn{3}{|l|}{ Full sample } & \multicolumn{3}{|c|}{ Asian Economies } \\
\hline & (1) & (2) & (3) & (4) & (5) & $(6)$ \\
\hline Country Size & $\begin{array}{l}3.996^{* * * *} \\
(0.802)\end{array}$ & $\begin{array}{l}4.501 * * * \\
(0.932)\end{array}$ & $\begin{array}{l}4.629 * * * \\
(1.262)\end{array}$ & $\begin{array}{l}1.502 * \\
(0.734)\end{array}$ & $\begin{array}{l}2.440 * * \\
(1.037)\end{array}$ & $\begin{array}{l}3.071 * * \\
(1.148)\end{array}$ \\
\hline Inflation volatility & $\begin{array}{l}0.580 * * * \\
(0.138)\end{array}$ & $\begin{array}{l}0.569 * * * \\
(0.142)\end{array}$ & $\begin{array}{l}0.544 * * * \\
(0.111)\end{array}$ & $\begin{array}{l}0.289 \\
(0.201)\end{array}$ & $\begin{array}{l}0.364 * \\
(0.179)\end{array}$ & $\begin{array}{l}0.404 * \\
(0.199)\end{array}$ \\
\hline Exchange rate volatility & $\begin{array}{l}0.133 * * * \\
(0.032)\end{array}$ & $\begin{array}{l}0.129 * * * \\
(0.029)\end{array}$ & $\begin{array}{l}0.109 * * \\
(0.034)\end{array}$ & $\begin{array}{l}0.036 \\
(0.034)\end{array}$ & $\begin{array}{l}0.049 \\
(0.036)\end{array}$ & $\begin{array}{l}0.045 \\
(0.038)\end{array}$ \\
\hline Exports & $\begin{array}{l}-0.063 * * \\
(0.025)\end{array}$ & $\begin{array}{l}-0.048 \\
(0.027)\end{array}$ & $\begin{array}{l}-0.089 \\
(0.051)\end{array}$ & $\begin{array}{l}-0.017 \\
(0.027)\end{array}$ & $\begin{array}{l}-0.012 \\
(0.023)\end{array}$ & $\begin{array}{l}0.025 \\
(0.040)\end{array}$ \\
\hline Institutional Quality & $\begin{array}{l}-0.312 * * * \\
(0.028)\end{array}$ & $\begin{array}{l}-0.367 * * * \\
(0.050)\end{array}$ & $\begin{array}{l}-0.439 * * * \\
(0.060)\end{array}$ & $\begin{array}{l}-0.203^{* *} \\
(0.068)\end{array}$ & $\begin{array}{l}-0.331 * * * \\
(0.068)\end{array}$ & $\begin{array}{l}-0.272 * * * \\
(0.065)\end{array}$ \\
\hline Monetary Independence & $\begin{array}{l}-1.653 * * \\
(0.645)\end{array}$ & $\begin{array}{l}-1.243 \\
(0.801)\end{array}$ & $\begin{array}{l}-0.558 \\
(0.964)\end{array}$ & $\begin{array}{l}-2.124 * * \\
(0.914)\end{array}$ & $\begin{array}{l}-2.169 * * \\
(0.909)\end{array}$ & $\begin{array}{l}-2.492 * * \\
(0.845)\end{array}$ \\
\hline Macroprudential policy & & $\begin{array}{l}-2.587 \\
(1.757)\end{array}$ & $\begin{array}{l}-3.025^{*} \\
(1.649)\end{array}$ & & $\begin{array}{l}-3.106^{*} \\
(1.634)\end{array}$ & $\begin{array}{l}-2.931^{*} \\
(1.500)\end{array}$ \\
\hline External debt & & & $\begin{array}{l}0.046 \\
(0.033)\end{array}$ & & & $\begin{array}{l}0.075^{*} \\
(0.035)\end{array}$ \\
\hline Constant & $\begin{array}{l}-35.446 * * \\
(11.843)\end{array}$ & $\begin{array}{l}-38.526^{* * *} \\
(10.896)\end{array}$ & $\begin{array}{l}-31.968 \\
(21.164)\end{array}$ & $\begin{array}{l}-10.233 \\
(13.408)\end{array}$ & $\begin{array}{l}-14.620 \\
(13.344)\end{array}$ & $\begin{array}{l}-30.898 \\
(16.963)\end{array}$ \\
\hline Observations & 200 & 200 & 190 & 70 & 70 & 70 \\
\hline Number of groups & 20 & 20 & 19 & 7 & 7 & 7 \\
\hline Country FE & Yes & Yes & Yes & Yes & Yes & Yes \\
\hline R-square & 0.211 & 0.230 & 0.258 & 0.129 & 0.202 & 0.229 \\
\hline Sargan-Hansen test ( $\mathrm{p}$-value) & 0.000 & 0.000 & 0.000 & 0.000 & 0.000 & 0.000 \\
\hline
\end{tabular}

The table presents the fixed-effect regression estimates for 20 emerging market economies (EMEs) as mentioned in Table 1. The sub-sample estimate for the Asian group includes China, India, Indonesia, Malaysia, Philippines, South Korea, and Thailand. The dependent variable is the currency mismatch indicator. The Drisc-Kraay standard errors are reported in parentheses to address heteroscedasticity, autocorrelation, and cross-sectional dependence across the countries. Sargan-Hansen test suggests the appropriateness of the fixed-effect model. The data for estimation is collected from the Bank for International Settlements (BIS), World Bank, International Monetary Fund (IMF), and international country risk guide of the PRS group. ***, **, and * denote statistical significance at $1 \%, 5 \%$ and $10 \%$ level

where $Y_{i, t}$ is the outcome variable-currency mismatch (as defined in Eq. 6) for country $i$ and year $t$. Alternatively, we employ original sin (as defined in Eq. 2) as a dependent variable. In Table 3, we present the description of explanatory variables and data sources. We estimate Eq. (7) to find the primary causes of currency mismatches and original sin alternatively. Using a novel dataset, we develop these foreign currency exposure indicators for 22 EMEs from 2008 to 2018. The empirical results are presented in Tables 4 and 5. We choose the fixed effect regression model as suggested by the Sargan-Hansen test. Further, we employ Drisc-Kraay's standard 
Table 5 Fixed-effect regression: causes of original sin

\begin{tabular}{|c|c|c|c|c|c|c|}
\hline \multirow[b]{2}{*}{ Variables } & \multicolumn{3}{|c|}{ Full sample } & \multicolumn{3}{|c|}{ Asian Economies } \\
\hline & (1) & (2) & (3) & (4) & (5) & (6) \\
\hline Country Size & $\begin{array}{l}-0.162 * * * \\
(0.047)\end{array}$ & $\begin{array}{l}-0.160 * * * \\
(0.046)\end{array}$ & $\begin{array}{l}-0.171^{* * * *} \\
(0.035)\end{array}$ & $\begin{array}{l}-0.304^{* * *} \\
(0.056)\end{array}$ & $\begin{array}{l}-0.283^{* * *} \\
(0.081)\end{array}$ & $\begin{array}{l}-0.321 * * * \\
(0.073)\end{array}$ \\
\hline Inflation volatility & $\begin{array}{l}0.001 \\
(0.002)\end{array}$ & $\begin{array}{l}0.001 \\
(0.002)\end{array}$ & $\begin{array}{l}0.002 \\
(0.002)\end{array}$ & $\begin{array}{l}0.008 \\
(0.009)\end{array}$ & $\begin{array}{l}0.010 \\
(0.010)\end{array}$ & $\begin{array}{l}0.007 \\
(0.010)\end{array}$ \\
\hline Exchange rate volatility & $\begin{array}{l}0.001 \\
(0.001)\end{array}$ & $\begin{array}{l}0.001 \\
(0.001)\end{array}$ & $\begin{array}{l}0.000 \\
(0.001)\end{array}$ & $\begin{array}{l}0.002 \\
(0.001)\end{array}$ & $\begin{array}{l}0.003 * \\
(0.001)\end{array}$ & $\begin{array}{l}0.003 * \\
(0.001)\end{array}$ \\
\hline Exports & $\begin{array}{l}-0.004 * \\
(0.002)\end{array}$ & $\begin{array}{l}-0.004 \\
(0.002)\end{array}$ & $\begin{array}{l}-0.006 * * \\
(0.002)\end{array}$ & $\begin{array}{l}-0.010^{* * * *} \\
(0.002)\end{array}$ & $\begin{array}{l}-0.009 * * * \\
(0.002)\end{array}$ & $\begin{array}{l}-0.012 * * * \\
(0.002)\end{array}$ \\
\hline Institutional Quality & $\begin{array}{l}-0.010^{* * *} \\
(0.003)\end{array}$ & $\begin{array}{l}-0.011^{* * *} \\
(0.002)\end{array}$ & $\begin{array}{l}-0.008^{* * * *} \\
(0.003)\end{array}$ & $\begin{array}{l}-0.011 \\
(0.012)\end{array}$ & $\begin{array}{l}-0.014 \\
(0.010)\end{array}$ & $\begin{array}{l}-0.017 \\
(0.010)\end{array}$ \\
\hline Monetary Independence & $\begin{array}{l}-0.012 \\
(0.043)\end{array}$ & $\begin{array}{l}-0.010 \\
(0.041)\end{array}$ & $\begin{array}{l}-0.049 \\
(0.033)\end{array}$ & $\begin{array}{l}-0.308 * \\
(0.168)\end{array}$ & $\begin{array}{l}-0.309 * \\
(0.168)\end{array}$ & $\begin{array}{l}-0.289 \\
(0.175)\end{array}$ \\
\hline Macroprudential policy & & $\begin{array}{l}-0.012 \\
(0.049)\end{array}$ & $\begin{array}{l}-0.005 \\
(0.045)\end{array}$ & & $\begin{array}{l}-0.069 \\
(0.132)\end{array}$ & $\begin{array}{l}-0.080 \\
(0.136)\end{array}$ \\
\hline External Debt & & & $\begin{array}{l}0.002^{* * * *} \\
(0.000)\end{array}$ & & & $\begin{array}{l}0.005 * * \\
(0.001)\end{array}$ \\
\hline Constant & $\begin{array}{l}3.438 * * * \\
(0.627)\end{array}$ & $\begin{array}{l}3.422 * * * \\
(0.641)\end{array}$ & $\begin{array}{l}3.283 * * * \\
(0.520)\end{array}$ & $\begin{array}{l}6.124 * * * \\
(1.490)\end{array}$ & $\begin{array}{l}6.026 * * * \\
(1.510)\end{array}$ & $\begin{array}{l}7.012 * * * \\
(1.393)\end{array}$ \\
\hline Observations & 200 & 200 & 190 & 70 & 70 & 70 \\
\hline Number of groups & 20 & 20 & 19 & 7 & 7 & 7 \\
\hline Country FE & Yes & Yes & Yes & Yes & Yes & Yes \\
\hline R-square & 0.166 & 0.167 & 0.256 & 0.403 & 0.411 & 0.431 \\
\hline Sargan-Hansen test ( $p$-value) & 0.000 & 0.000 & 0.000 & 0.000 & 0.000 & 0.000 \\
\hline
\end{tabular}

The table presents the fixed-effect regression estimates for the full 20 emerging market economies (EMEs) as mentioned in Table 1. The sub-sample estimate for the Asian group includes China, India, Indonesia, Malaysia, Philippines, South Korea, and Thailand. The dependent variable is the original sin indicator. The Drisc-Kraay standard errors are reported in parentheses to address heteroscedasticity, autocorrelation, and cross-sectional dependence across the countries. The Sargan-Hansen test suggests the appropriateness of the fixed-effect model. The data for estimation is sourced from the Bank for International Settlements (BIS), World Bank, International Monetary Fund (IMF), and international country risk guide of the PRS group. ***,**, and $*$ denote statistical significance at $1 \%, 5 \%$ and $10 \%$ level

errors to address the issue of autocorrelation, heteroskedasticity, and cross-sectional dependence in panel regression.

The estimates of model (1) in Table 4 shows that the coefficient of country size is positive and significant, indicating large size countries having high currency mismatches (liability position in foreign currency). These results suggest that the size gives the borrowers an advantage to raise funds from global markets, given their credibility. Further, we use inflation volatility to measure monetary credibility. The result shows that higher inflation volatility leads to high currency mismatches in EMEs. Such volatility questions the credibility of monetary policy. This result 
implies that inflation volatility increases the country's risk leading to borrowing in foreign currency. Such borrowings result in currency mismatches. Our finding is in line with the results of Lane and Shambaugh (2010) and Baek (2013).

In the same line, currency risk and domestic instability can be measured with exchange rate volatility. The coefficient of exchange rate volatility is significant and positively associated with currency mismatches. Goldstein and Turner (2004) consider exchange rate volatility as a weakness of EMEs. Such volatility increases the private foreign currency borrowings, which increases the net liability position. The result implies that exchange rate volatility causes a currency mismatch problem, consistent with the currency risk model. Further, we find that higher export earnings lower the currency mismatch problem. The finding is as per the theoretical expectation.

Previous studies show that poor institutional quality lowers the domestic credit facilities leading to high foreign currency borrowings and currency mismatches (see Goldstein and Turner 2004; Lane and Shambaugh 2010; Baek 2013). We show that the institutional quality is negative and significant at one percent significance level. Our evidence strongly suggests that institutional quality is a crucial factor in controlling currency mismatches. This finding supports the theoretical and empirical evidence on the importance of quality institutions in EMEs. Similarly, the monetary independence of an economy determines the currency mismatches. For example, Bianchi and Mondragon (2018) argue that lack of monetary independence aggravates external vulnerability and raises the incidence of the sovereign debt crisis. We use the monetary independence index developed by Aizenman et al. (2013) to establish the link between monetary independence and currency mismatches. We find the coefficient of Aizenman et al. (2013) index negative, implying that the monetary independence reduces the currency mismatches and external vulnerability (model 1 in Table 4).

Recent policy focus in EMEs is to measure and prevent external imbalances. The macroprudential policies possibly minimize the systemic risk and external shocks and thus assumes importance. In this context, we test the importance of implementing prudential policies to control currency mismatches. We use a binary variable in which the value of one indicates when a country imposes limits on foreign currency loans and zero otherwise (see Cerutti et al. 2017). We find the coefficient negative and significant, indicating a stronger association between prudential policies and liability position in foreign currency (model 3 in Table 4). The result implies that prudential policies decrease the vulnerability of currency risk. Finally, we test the role of fiscal policies in explaining currency mismatches. We use the external debt as a percentage of GDP in our empirical model (3) to examine the relationship. Our estimates suggest that weak fiscal policy (unsustainable external and public debt levels) leads to higher inflation and country risk, further aggravating currency mismatches. This result validates the theoretical view of Goldstein and Turner (2004). Thus, we confirm the importance of fiscal policy in controlling currency mismatches.

We re-estimate Eq. (7) for select Asian economies to ensure robustness (models 4 to 6 in Table 4). Asian economies hold a larger amount of foreign currency assets. This region's performance in controlling currency mismatches is better than the other group of EMEs (see Section 3). Therefore, understanding the causes of foreign 
exposure in these economies gives an intriguing lesson for the EME peers. The estimates confirm the consistency and robustness of the baseline inferences. The relationship of currency mismatches in Asia is directly related to the country size and inflation volatility, as in the full sample analysis. The exports play no major role in neither full sample nor sample from Asia. However, we show that the exchange rate volatility is not a significant factor to cause the currency mismatches in Asia, as the coefficient is statistically insignificant. The result indicates the effectiveness of the monetary policy in these economies. In Asia, emphasis on monetary policy independence, macroprudential policies, and efforts to reduce the external debt paid off, as evident from the panel estimates. Relatively, Asia did well on these fronts to control the currency mismatches.

Further, we follow the baseline model specifications and re-estimate Eq. (7) to examine the causes of original sin in EMEs. We use the original sin index as an outcome variable with the same set of regressors and present the estimates in Table 5. We find a direct relationship of inflation, exchange rate volatility, and external debt with the original sin. In contrast, the institutional quality, monetary independence, and macroprudential policies are inversely related to the original sin. In other words, these factors lessen the problem of original sin. The evidence on determinants of original sin is similar to that of the currency mismatches except country's size. We find an inverse relationship between a country's size and the original sin. This finding is consistent with the evidence of Eichengreen et al. (2007). They argue that large-sized countries such as the US and Japan are immune to the original sin than small countries. As in the case of currency mismatches, the coefficient of export is theoretically consistent but not statistically insignificant.

Similarly, we re-estimate Eq. (7) with original sin as the dependent variable for Asia. The estimates are not significantly different from the full sample. Nevertheless, the effect of inflation volatility on original sin is not significant, showing that inflation in Asian economies is within bounds. The monetary policy played an important role in ensuring stable inflation. As in the case of currency mismatches, Asian economies successfully reduce the original sin by ensuring monetary policy independence, implementing macroprudential policies, and reducing the external debt. It shows the effectiveness of fiscal policy in EMEs. The significance of institutional quality further conforms to these inferences. The Asian countries developed the domestic markets to lessen the dependence on foreign currency borrowings.

\section{Concluding remarks and policy implications}

This paper revisits the core question of original sin and currency mismatches by employing a novel dataset on foreign currency assets and liabilities. We analyze the foreign currency exposure by measuring original sin and currency mismatches in 22 EMEs for 2008-2018. Our analysis reveals that many EMEs are exposed to currency risk at an alarming level. Notably, we find the highest average original sin for Latin American countries, followed by Central European economies. This finding 
reminds the growing exposures preceding the financial crises in Latin America in 1994 and Asia in 1997.

Further, the magnitude of the currency mismatch problem is severe in the country with greater original sin and net liability position in foreign currency. Therefore, we argue that a higher value of original sin and currency mismatches destabilize the financial system and increase the probability of financial crises in EMEs. The rapid accumulation of foreign currency-denominated debt led to the currency crisis in Argentina and Turkey in 2018, reinforcing our view. In this context, the recent resurgence of currency mismatches accompanied by the post-Covid-19 economic situation is the stress test for monetary and fiscal policy frameworks.

The EMEs have been pursuing an export-led growth strategy since the early 1990s. We suggest that EMEs need to continue this strategy to earn foreign currency assets through export earnings and ensure forex reserves to control currency mismatches and original sin problems. The forex reserves can safeguard the economy from shock emanating due to systemic risk and external vulnerability. Such reserves ensured lower currency depreciation during the taper tantrum crisis. Our empirical results indicate that the currency mismatch is lower in countries that follow de-dollarization policies such as limiting debt exposure.

Nevertheless, debt is indispensable to fuel economic growth, which in turn pulls out the people from poverty and maintains a reasonable standard of life in EMEs. These economies are benefitted from financial integration and globalization, and foreign currency borrowing boosted growth in EMEs. Therefore, EMEs need to adopt those policies, which are consistent with their growth-oriented policies. A total aversion to foreign currency-denominated debt is not advisable, as the firms need such financing in line with their corporate strategy. The same is true for sovereign authority in a global setting. The solution lies in the monetary policy independence, which plays a vital role in maintaining stable inflation and exchange rate that are proved beneficial to restrain currency mismatches within a limit. Our evidence suggests that the monetary policy independence in the sample EMEs helped reduce the original sin and currency mismatches. The fiscal policy reduced the burden of external debt and thus improved the resilience of the economy. The macroprudential policies accompanied by strong domestic institutions help control mismatches without affecting the financial leverage, which is essential for economic growth. Finally, the success story of Brazil, China, India, and South Africa in developing the offshore bond markets in local currency holds lessons for other EMEs to reduce currency mismatches.

Our study is limited to aggregate balance sheet information. An examination of the corporate balance sheet provides additional insights into the risk of the corporate sector. A growth model accommodating currency mismatches may also provide a broader framework for the analysis. Future research can extend on this front.

Acknowledgements We thank anonymous reviewer for helpful comments and suggestions on an earlier version of the paper. We also thank Prof. Ashima Goyal and for their most insightful suggestions. An earlier version of the paper was presented in 18th Annual Conference on Macoreconomics and Finance organized by Indira Gandhi Institute of Development Research, Mumbai, India. Responsibility for any error resulting in this work remains our own. 


\section{References}

Aizenman J, Chinn MD, Ito H (2013) The "impossible trinity" hypothesis in an era of global imbalances: Measurement and testing. Rev Int Econ 21(3):447-458

Arslanalp MS, Tsuda MT (2014) Tracking global demand for emerging market sovereign debt. International Monetary Fund, Working paper No. 14-39

Baek SG (2013) On the determinants of aggregate currency mismatch. Journal of Policy Modeling 35(4):623-637

Bianchi J Mondragon J (2018) Monetary independence and rollover crises. Natl Bur Econ Res (No. w755), 1-47

BIS (Bank for international settlements) (2019) Monetary policy frameworks in EMEs: inflation targeting, the exchange rate and financial stability. BIS Annual Economic Report, 31-53

Cerutti E, Claessens S, Laeven L (2017) The use and effectiveness of macroprudential policies: New evidence. J Financ Stab 28:203-224

Chui M Kuruc E, Turner P (2016) A new dimension to currency mismatches in the emerging markets non-financial companies. BIS, Working Paper, No.550

Chui M, Kuruc E, Turner P (2018) Leverage and currency mismatches: Non-financial companies in the emerging markets. World Econ 4(2):1-19

Du W, Schreger J (2016) Sovereign risk, currency risk, and corporate balance sheets. Harvard Business School BGIE Unit, Working Paper No.17-024

Eichengreen B, Hausmann R, Panizza U (2005a) The pain of original sin. Other People's Money: Debt Denomination and Financial Instability in Emerging Market Economies. University of Chicago Press, Chicago, pp 13-47

Eichengreen B, Hausmann R, Panizza U (2005b) The mystery of original sin. Other People's Money: Debt Denomination and Financial Instability in Emerging Market Economies. University of Chicago Press, Chicago, pp 233-265

Eichengreen B, Hausmann R, Panizza U (2007) Currency mismatches, debt intolerance, and the original sin: Why they are not the same and why it matters. Capital controls and capital flows in emerging economies: Policies, practices and consequences. University of Chicago Press, Chicago, pp 121-170

Gagnon JE (2014) Currency and maturity mismatches in Asia. Asian Capital Market Development and Integration - Challenges and Opportunities. Oxford University Press for Korean Capital Market Institute and Asian Development Bank, 3-30

Goldstein M, Turner P (2004) Controlling currency mismatches in emerging markets. Institute for International Economics. Columbia University Press, Washington, DC

Hiremath, G.S (2016). External commercial borrowings and balance sheet effects of exchange rate in India: A firm level analysis A draft report submitted to the Reserve Bank of India, Mumbai. Available at SSRN: https://ssrn.com/abstract=3658325 or https://doi.org/10.2139/ssrn.3658325

Hofmann B Shim I, Shin HS (2020) Emerging market economy exchange rates and local currency bond markets amid the Covid-19 pandemic. BIS Bulletins, 1-7

IIF (The Institute of International Finance) (2019) Global debt monitor devil in the details. IIF reports $1-5$

Kamil H (2012) How do exchange rate regimes affect firms' incentives to hedge currency risk? Micro evidence for Latin America. International Monetary Fund (WP. 12/69), 1-54

Kohli R Sahoo P, Shuheb Khan M (2017) Developing India's offshore local currency bond market: Lessons from emerging countries. Indian Council for Research on International Economic Relations, Working Paper (No. 344)

Kuruc E Tissot B, Turner P (2016) Looking at aggregate currency mismatches and beyond. BIS (Ed.), Conference on Uses of Central Balance Sheet Data Offices' information, 45

Lane PR, Shambaugh JC (2010) Financial exchange rates and international currency exposures. Am Econ Rev 100(1):518-540

Levy-Yeyati E (2006) Financial dollarization: Evaluating the consequences. Econ Policy 21(45):61-118

Montoro C, Rojas-Suarez L (2012) Credit at times of stress: Latin American lessons from the global financial crisis. BIS (WP. No. 370), 1-44 
Park YC (2011) Reform of the global regulatory system: perspectives of East Asia's emerging economies. In: Lin, J. Y. and Pleskovič, B. (Eds.) (2011). Lessons from East Asia and the global financial crisis. pp. 187-211. World Bank. https://doi.org/10.1596/978-0-8213-8060-4

Tobal M (2013) Currency Mismatch: New database and indicators for Latin America and the Caribbean. Cemla Research Papers, 12

Publisher's note Springer Nature remains neutral with regard to jurisdictional claims in published maps and institutional affiliations.

\section{Authors and Affiliations}

\section{Hari Venkatesh $^{1}$ (D) Gourishankar S. Hiremath ${ }^{1}$}

Gourishankar S. Hiremath gshiremath@hss.iitkgp.ac.in

1 Department of Humanities and Social Sciences, Indian Institute of Technology Kharagpur, Kharagpur, West Bengal 721302, India 